\title{
Differential Saturation Electroantennogram of Germacrene-D, a Sex Pheromone Mimic of the American Cockroach
}

\author{
Chikao Nishino and Shunichi Manabe \\ Mitsubishi-Kasei Institute of Life Sciences, \\ Minamiooya, Machida 194, Japan
}

(Received September 9, 1983) !

\begin{abstract}
By applying differential saturation EAG (DS-EAG) technique, the olfactory receptor for germacrene-D (1), a sex pheromone mimic of the American cockroach, was investigated using natural sex pheromones [periplanone-A (2) and periplanone-B (3)], a general odor (camphor) and this mimic. The mimic was consequently revealed to be involved in the sex pheromone receptor responsible for periplanone-A in preference to that for periplanone-B.
\end{abstract}

\section{INTRODUCTION}

Since a plant component, germacrene-D (1), was reported as a sex pheromone mimic of the American cockroach (Periplaneta americana L..), ${ }^{1)}$ several investigators ${ }^{2,3)}$ have made effort to deduce the structural factors important for sex pheromonal activity included in $\mathbf{1}$ by preparing analogs of $\mathbf{1}$. Major interest in these works was based on the structural similarity between 1 and periplanone-B $(\mathbf{3})^{4-6)}$ which is a natural sex pheromone isolated from females of the insect together with another sex pheromone, periplanone-A (2). ${ }^{7,8)}$ Clear structural relationship between $\mathbf{1}$ and $\mathbf{3}$ has not been deduced.

Quite recently, we ${ }^{9)}$ employed the differential saturation electroantennogram (DSEAG) method in order to elucidate the olfactory receptor system for the monoterpenoid sex pheromone mimics ${ }^{10,11)}$ of the cockroach. The mimics were consequently revealed to be involved in the sex pheromone receptors responsible for $\mathbf{3}$.

In this work, an investigation on the olfactory receptor system for $\mathbf{1}$ was conducted by employing DS-EAG technique in order to establish a basic conception for elucidating structural relation of $\mathbf{1}$ with the natural pheromone(s).

\section{MATERIALS AND METHODS}

\section{Odorous Compounds for DS-EAG}

Germacrene-D (1) was isolated from a Compositae plant, Solidago altisimma L. Pure natural sex pheromones, $\mathbf{2}$ and $\mathbf{3},{ }^{12}$ ) isolated from the female cockroaches were used. Camphor as a general odor was obtained commercially. Five hundreds micrograms of $\mathbf{1}$ and camphor, and, $1 \times 10^{-2} \mu \mathrm{g}$ of $\mathbf{2}$ and $\mathbf{3}$ were suitable quantities as the primary odorous stimulation to saturate the antennae, while $100 \mu \mathrm{g}$ of 1 and camphor, and $2 \times 10^{-3}$ of the pheromones were used for the secondary stimulation to the saturated antennae.

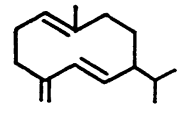

1

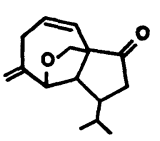

2

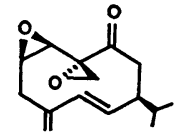

3

\section{Isolation of $\mathbf{1}^{2)}$}

The aerial parts except for flowers $(12.5 \mathrm{~kg})$ (collected near Tokyo in October) were extracted with methanol (48l) for 1 month at 
room temperature. After removal of the solvent to $4 l$ aqueous concentrate, the ethyl acetate extract from the aqueous solution was equally divided into 3 portions. For each portion, Florisil (495 g) column chromatography (column: $4.5 \times 60 \mathrm{~cm}$ ) was performed by eluting with $n$-hexane ( 1 fraction $=1.3 l$ ). Fractions with same numbers were combined and analyzed by GC $(4 \% \mathrm{OV}-1$ in a $2 \mathrm{~m} \times$ $3 \mathrm{~mm}$ column, $\left.145^{\circ} \mathrm{C}, \mathrm{N}_{2} 50 \mathrm{ml} / \mathrm{min}\right)$. The presence of 1 was shown in fractions 1-3 (9.0 g). For $1 \mathrm{~g}$ of the fractions, $10 \% \mathrm{AgNO}_{3}$ Florisil column chromatography (120 g) was performed eluting with $n$-hexane containing increasing proportions $(0,5,10, \ldots, 90,95$ and $100 \%$ ) of chloroform (column: $3 \times 60 \mathrm{~cm}, 1$ fraction $=200 \mathrm{ml}$ ). Subsequently, the column was eluted with a mixture of chloroform and ether, in which the concentration of ether was increased in successive 5\% steps. Germacrene$\mathrm{D}$ (1) was included in $50-100 \%$ ether in chloroform fractions in each of the chromatography with $1 \mathrm{~g}$ sample. Such chromatography was repeated 9 times. The fractions $(5.8 \mathrm{~g})$ were chromatographed over neutral aluminum oxide $(50 \mathrm{~g})$ (column: $3.5 \times 40 \mathrm{~cm}$ ) eluting with n-hexane. Fractions having 1 (2.7 g) were subjected to HPLC [sample: $100 \mathrm{mg}$, Develosil 30-3 $(3 \mu \mathrm{m})$ in a $4 \mathrm{~mm} \times 15 \mathrm{~cm}$, column, solvent: $n$-hexane $(1.1 \mathrm{ml} / \mathrm{min})]$. Finally 2.7 $\mathrm{g}$ of the fractions gave $1.9 \mathrm{~g}$ of pure $\mathbf{1} ;[\alpha]_{\mathrm{D}}^{25^{\circ}}$ $-59.8^{\circ} \quad(c=1.00, n$-hexane $),-19.2^{\circ} \quad(c=1.00$, $\mathrm{MeOH}$ ) (based on the value by Niwa, ${ }^{13)}$ our 1 was composed of a mixture of (-)- and (+)1 with $53: 47$ ratio); UV ( $n$-hexane): $\lambda_{\max }$ $259 \mathrm{~nm} \quad(\epsilon=4500)$; IR (film): $\nu_{\max } 3070$, $1630,1605,1390,1375,880 \mathrm{~cm}^{-1}$; PMR $\left(\mathrm{CCl}_{4}, 60 \mathrm{MHz}\right): \delta_{\mathrm{ppm}}^{\mathrm{TMS}} 0.80[3 \mathrm{H}$, doublet $(\mathrm{d})$, $J=6 \mathrm{~Hz}], 0.86(3 \mathrm{H}, \mathrm{d}, J=6 \mathrm{~Hz}), 1.46[3 \mathrm{H}$, broad singlet (bs)], $4.69(2 \mathrm{H}, \mathrm{bs}), 5.10(1 \mathrm{H}$, multiplet), 5.18 ( $1 \mathrm{H}$, double doublet, $J=16$ and $9 \mathrm{~Hz}), 5.73(1 \mathrm{H}, \mathrm{d}, J=16 \mathrm{~Hz}) ; \mathrm{MS}: m / z$ $204\left(\mathrm{M}^{+}, \mathrm{C}_{15} \mathrm{H}_{24}\right), 161\left(\mathrm{M}^{+}-43\right.$, base peak $)$, $120,105,81,79,41 ; \mathrm{GC}$ retention time $\left(t_{R}\right.$, $\min ) 7.1$; HPLC: $t_{R} 4.8$.

\section{Odor Delivery System, ${ }^{9)}$ Antennal Prepara- tion and Response Recording in DS-EAG (Fig. 1)}

By turning a 3-way stop-cock (b), we introduced a continuous air-stream (a, $30 \mathrm{ml} / \mathrm{sec}$ ) escaping from the path d into a $10 \mathrm{ml}$ syringe $\left(e_{1}\right)$ through the path c. A filter paper $\left(f_{1}\right.$, $1.3 \mathrm{~cm}$ diameter) inpregnated with a high concentration of a primary odor for saturation was placed on a vinyl holding tube (g) in the syringe, so that the air-stream (h) after having passed through the filter paper $\left(f_{1}\right)$ contained sufficient quantities of the primary odor. While the antenna was saturated by the primary odor, secondary odorous stimulation was carried out by pressing the plunger (i) of another $10 \mathrm{ml}$ syringe $\left(\mathrm{e}_{2}\right)$ in which a filter paper $\left(f_{2}\right)$ impregnated with the secondary odor was equipped. Consequently, an airstream ( $\mathrm{j}$ ) with both primary and secondary odors was applied to an antenna (k).

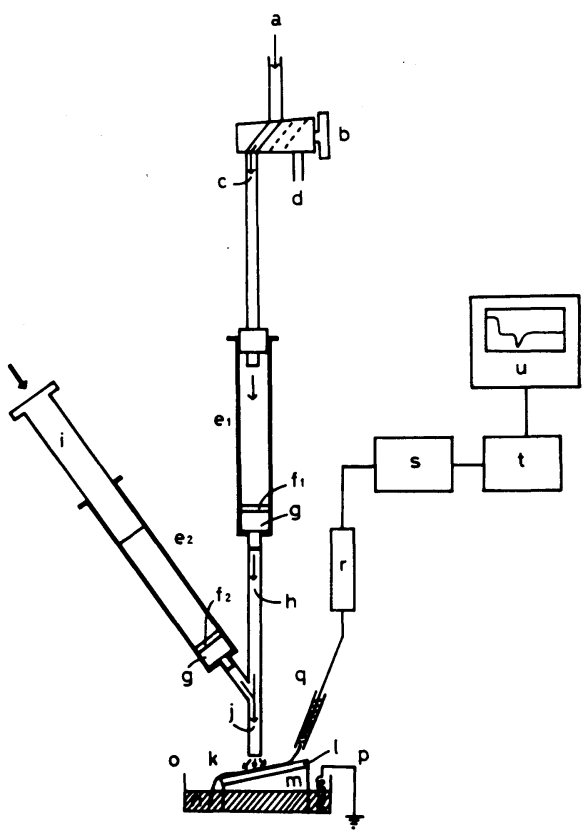

Fig. 1 Schematic drawing of odor delivery system and antennal preparation for the differential saturation EAG (DS-EAG) recording.

a: air-stream, b: 3-way stopcock, c: path for odor saturation, $d$ : path for escaping, $e_{1}$ and $e_{2}$ : $10 \mathrm{ml}$ syringe, $f_{1}$ : filter paper with primary odor, $\mathrm{f}_{2}$ : filter paper with secondary odor, $g$ : vinyl tubing holder, h: air-stream with primary odor, $\mathrm{i}$ : syringe plunger, $\mathrm{j}$ : air-stream with both primary and secondary odors, $\mathrm{k}$ : male antenna, 1 : glass slide, $\mathrm{m}$ : rubber stand, $\mathrm{n}$ : cockroach sarine, $\mathrm{o}:$ Petri dish, $\mathrm{p}:$ indifferent electrode, $\mathrm{q}:$ recording electrode, $\mathrm{r}$ : probe, $\mathrm{s}$ : micro-electrode amplifier, $\mathrm{t}$ : biophysical amplifier, $\mathrm{u}$ : wave memory scope. 
After $1 \mathrm{~mm}$ of the tip of an excised antenna (k) of an adult male of the cockroach was cut off the antenna was fixed with small pieces of adhesive tape on a glass slide (1) on an angled rubber stand $(\mathrm{m})$ in a $50 \mathrm{~mm}$ diameter Petri dish (o) filled with cockroach saline solution (n). The scape end of the antenna was immersed into a medium permitting electrical connection of the antenna with an indifferent electrode ( $\mathrm{p}$, spiral chlorided silver wire). A distal end of the antenna was inserted into a recording electrode (g) (glass capillary composed of chloridized silver wire and the saline solution). The recording electrode was connected to a microelectrode amplifier [s, Model DPZ-11, Dia-medical System Co. (Tokyo)] via a probe (r, Model DPZ-101). The amplified signal was further amplified with a biophysical amplifier ( $t$, Model DPA-100F). The EAG response was visible on an oscilloscope of a wave memory apparatus ( $\mathrm{u}$, Model DPM-202). One antenna was used for the saturation with one primary odor. While the antenna was saturated, secondary odorous stimulations were performed using all the secondary odors. Such test was repeated 3 times. The average EAG amplitudes were obtained from the 3 tests with standard deviations (see Table 1).

\section{RESULTS}

Typical EAG response patterns in DSEAG are shown in Fig. 2, and the expression with figures (average amplitude \pm standard deviation of 3 tests) is shown in Table 1.

The quantities of every compound used elicited large responses more than $0.8 \mathrm{mV}$ [Fig. 2-I, $a$ (camphor, $100 \mu \mathrm{g}), b(\mathbf{1}, 100 \mu \mathrm{g})$, $c\left(\mathbf{2}, 2 \times 10^{-3} \mu \mathrm{g}\right)$ and $\left.d\left(3,2 \times 10^{-3} \mu \mathrm{g}\right)\right]$ in the usual EAG recording. These responses are much higher than the control response (I-e, without compound). Saturated bases [II- $A$ (camphor, $500 \mu \mathrm{g})$, III- $B(\mathbf{1}, 500 \mu \mathrm{g})$, IV-C $\left(2, \quad 1 \times 10^{-2} \mu \mathrm{g}\right)$ and $\left.\mathrm{V}-D\left(3,1 \times 10^{-2} \mu \mathrm{g}\right)\right]$ elicited $0.7-1.5 \mathrm{mV}$. Against the saturated bases, secondary stimulation with a compound, when the same compound was used for saturation, gave small or negligible responses $[$ II- $a / A(0.25 \mathrm{mV})$, III- $b / B(0.15 \mathrm{mV})$, $\mathrm{IV}-c / C \quad(0.01 \mathrm{mV})$ and $\mathrm{V}-d / D \quad(0.10 \mathrm{mV})]$. These responses were comparable to the control response $(\mathrm{II}-e \mid A)$ in which air without

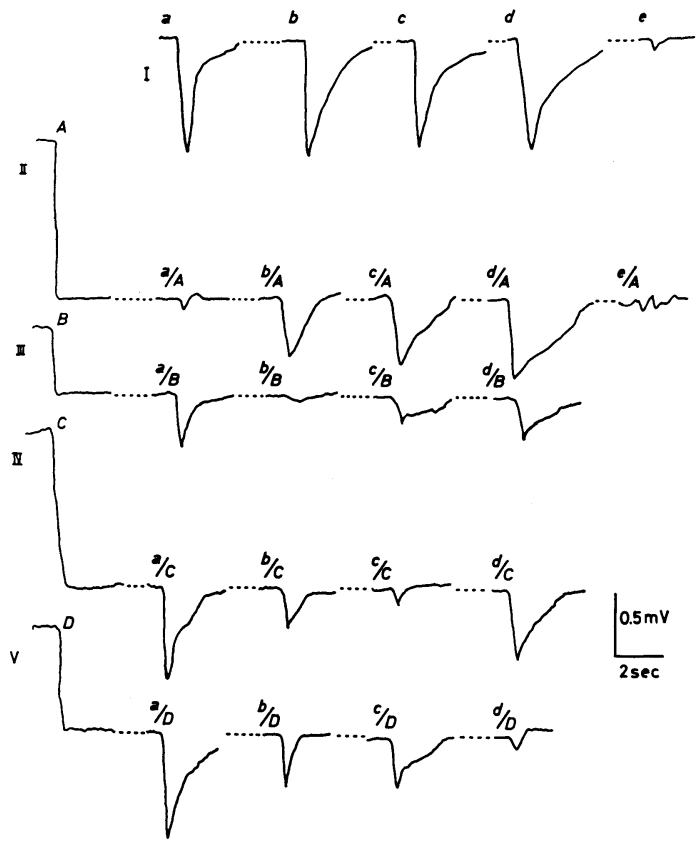

Fig. 2 Typical EAG responses recorded in DSEAG experiments by stimulation with camphor (general odor), germacrene-D (1, sex pheromone mimic), periplanone-A and periplanone-B ( 2 and 3 respectively, sex pheromones).

$\mathrm{I}$ : responses induced by $100 \mu \mathrm{g}$ of camphor $(a)$, $100 \mu \mathrm{g}$ of $1(b), 2 \times 10^{-3} \mu \mathrm{g}$ of $2,(c), 2 \times 10^{-3} \mu \mathrm{g}$ of $3(d)$ and air $(e)$ to the base line given by continuous air-stream only. II: responses induced by secondary stimulations with the above quantities of the compounds to the base line saturated with $500 \mu \mathrm{g}$ of comphor $(A)$, in which, for example, $a / A$ indicates a response obtained from secondary stimulation with $100 \mu \mathrm{g}$ of camphor to the base saturated with $500 \mu \mathrm{g}$ of camphor. Similar stimulations were performed to the base lines produced by saturation with $500 \mu \mathrm{g}$ of $\mathbf{1}$ (III- $B$ ), $1 \times 10^{-2} \mu \mathrm{g}$ of 2 (IV-C) and $1 \times 10^{-2} \mu \mathrm{g}$ of $3(\mathrm{~V}-D)$.

odor was used as secondary stimulation. This indicates that receptor saturation by the primary odorous compounds was perfect.

To the camphor-saturated base line (II- $A$ ), the compounds active as sex pheromone evoked large secondary responses [II- $b / A$ $(0.51 \mathrm{mV}), \mathrm{II}-c / A(0.50 \mathrm{mV})$ and II- $d / A(0.75$ $\mathrm{mV})]$. On the other hand, camphor evoked large secondary responses against the base 
Table 1 EAG amplitudes $(\mathrm{mV})$ of the adult male American cockroach in differential saturation experiments.

\begin{tabular}{|c|c|c|c|c|c|}
\hline & & \multicolumn{4}{|c|}{ Primary odor for saturation } \\
\hline & & $\begin{array}{c}\text { Camphor } \\
(500 \mu \mathrm{g})\end{array}$ & $\begin{array}{c}\mathbf{1} \\
(500 \mu \mathrm{g})\end{array}$ & $\begin{array}{c}\mathbf{2} \\
\left(1 \times 10^{-2} \mu \mathrm{g}\right)\end{array}$ & $\begin{array}{c}3 \\
\left(1 \times 10^{-2} \mu \mathrm{g}\right)\end{array}$ \\
\hline \multicolumn{2}{|c|}{ Saturated base line } & $1.18 \pm 0.28$ & $0.73 \pm 0.17$ & $1.50 \pm 0.18$ & $0.86 \pm 0.13$ \\
\hline \multirow{4}{*}{$\begin{array}{l}\text { Odor for secondary } \\
\text { stimulation } \\
\text { (amplitude from } \\
\text { saturated base line) }\end{array}$} & Camphor $(100 \mu \mathrm{g})$ & $0.25 \pm 0.13$ & $0.51 \pm 0.13$ & $0.50 \pm 0.09$ & $0.75 \pm 0.17$ \\
\hline & $\mathbf{1}(100 \mu \mathrm{g})$ & $0.48 \pm 0.10$ & $0.15 \pm 0.08$ & $0.19 \pm 0.03$ & $0.35 \pm 0.08$ \\
\hline & $2\left(2 \times 10^{-3} \mu \mathrm{g}\right)$ & $0.88 \pm 0.25$ & $0.44 \pm 0.18$ & $0.01 \pm 0.02$ & $0.32 \pm 0.07$ \\
\hline & $3\left(2 \times 10^{-3} \mu \mathrm{g}\right)$ & $0.95 \pm 0.25$ & $0.64 \pm 0.26$ & $0.31 \pm 0.04$ & $0.10 \pm 0.06$ \\
\hline
\end{tabular}

Each amplitude is given by average value \pm standard deviation of 3 tests. Values in the line "saturated base line" means the amplitudes after having been saturated by compounds and thus became base lines for secondary odorous stimulations (see II- $A$, III- $B$, IV- $C$ and V- $D$ in Fig. 2). The other amplitudes were measured for the responses from the saturated base lines whose shapes are typically shown in $a / A, b / A, \cdots \cdots, c / D$ and $d / D$ in Fig. 2.

lines saturated with compounds active as sex pheromone $[\mathrm{III}-a / B \quad(0.48 \mathrm{mV}) ; \mathrm{IV}-a / C$ $(0.88 \mathrm{mV})$ and $\mathrm{V}-a / D(0.95 \mathrm{mV})]$. These facts imply that receptors responsible for camphor are different from those for the sex pheromonal compounds. "General odor receptor" has been proposed by the authors ${ }^{14)}$ for the receptors responsible for general odors such as food odors including camphor. The receptors are scattered on the antennae of both male and female. On the other hand, "special odor receptors"14) are sensitive to special odors such as sex pheromones, and exist on male antennae only.

In the saturation experiments with 1 (Fig. 2-III), although both natural pheromones gave significant secondary EAG responses, the response by $2[\mathrm{III}-c / B(0.44 \mathrm{mV})]$ was weaker than that by $3[\mathrm{III}-d / B(0.64 \mathrm{mV})]$. In this case, camphor evoked somewhat weaker secondary response as compared with the other saturation experiments (see III- $a / B$ comparing with $\mathrm{IV}-a / C$ and $\mathrm{V}-a / D)$. This suggests that $\mathbf{1}$ is weakly associated with general odor receptors. It is known that $\mathbf{1}$ stimulates significantly general odor receptors on the female antennae of the cockroach. ${ }^{14)}$ When the antennae were saturated with $\mathbf{2}$ (see IV), the secondary stimulation with $\mathbf{1}$ elicited weaker response $[\mathrm{IV}-b / C(0.19 \mathrm{mV})]$ as compared with $\mathbf{3}[\mathrm{IV}-d / C(0.31 \mathrm{mV})]$. In the case of saturation with $\mathbf{3}$ (see $\mathrm{V}$ ), secondary responses by $\mathbf{1}$ and $\mathbf{2}(\mathrm{V}-b / D$ and $c / D)$ yielded similar amplitudes $(0.35$ and $0.32 \mathrm{mV}$, respectively). From these evidences, the following conclusions may be induced: (1) Either sex pheromone (2 or $\mathbf{3}$ ) has a specific receptor (periplanone-A receptor or periplanone-B receptor), which supports the conclusions reported in the single cell recording work $^{15)}$ and our previous EAG work ${ }^{9)}$; (2) Germacrene-D (1) is associated with both of the sex pheromone receptors, but seems to be involved preferentially in the periplanone-A receptor to in the periplanone- $\mathrm{B}$ receptor.

\section{DISCUSSION}

DS-EAG technique developed for beetles ${ }^{16,17)}$ and moths ${ }^{18)}$ involves an aspect that insect olfactory receptors successfully saturated with a high concentration of a compound in a continuous air-stream (primary odorous stimulation) will not respond to further stimulation (secondary odorous stimulation) with the saturating compound, but will still respond from other antennal receptors to secondary stimulation with other types of compounds.

Using this technique, we discovered important facts for the olfactory receptor systems on the male antennae of the American cockroach in a previous work ${ }^{9}$ which was undertaken for solving a problem of the structural relationship between the monoterpenoid sex pheromone mimics with the verbenyl skeleton and the natural sex pheromones. The following aspects have been 
revealed from the study, (i) the presence of general odor receptors which are different from sex pheromone receptors; (ii) the presence of two types of sex pheromone receptors specifically responsible for $\mathbf{2}$ and $\mathbf{3}$ and (iii) strong interaction of the verbenyl monoterpenoid sex pheromone mimics with the periplanone-B receptor. According to the above DS-EAG results, we are inspecting the structural overlap between a monoterpenoid mimic $[(+)$-verbanyl propionate $]$ and $\mathbf{3} \mathrm{em}$ ploying Dreiding models and computer graphics. Since the structural overlap between $(+)$ bornyl acetate and (+)-trans-verbenyl acetate was elucidated, ${ }^{19)}$ all the monoterpenoid sex pheromone mimics seem to be involved in periplanone-B receptor.

Burrows et al. ${ }^{15)}$ have reported the first two $[$ (i) and (ii)] of the above findings in their single cell recording studies in which they recognized two types of sex pheromone receptor cells, one being selectively responsible to $\mathbf{2}$ and the other to $\mathbf{3}$, and the presence of cells for food (general) odors.

In the present EAG work, surprisingly $\mathbf{1}$ seems to interact strongly with the periplanoneA receptor rather than the periplanone-B receptor. However, in order to give a structural correlation between $\mathbf{1}$ and 2, it may be further required to synthesize oxygen-containing germacrene- $\mathrm{D}$ derivatives and to evaluate their sex pheromonal activity. For syntheses of these compounds, an information is proposed by Niwa et al. ${ }^{20}$ who derived two compounds with the same carbon skeleton as that of $\mathbf{2}$ from epoxygermacrene-D, a derivative of $\mathbf{1}$, upon treatment with basic alumina.

Concerning general odor receptors, two types of receptors which are responsible for carbony and alcoholic compounds are known from our EAG works. ${ }^{21,22}$ In a single cell recording study, ${ }^{23)}$ the presence of general odor receptors for amines, acids, esters and unsaturated (cf. 1) compounds together with the above two types of cells are recognized.

\section{ACKNOWLEDGEMENTS}

We acknowledge technical assistance from Miss K. Kuwabara.

\section{REFERENCES}

1) S. Tahara, M. Yoshida, J. Mizutani, C. Kitamura \& S. Takahashi: Agric. Biol. Chem. 39, 1517 (1975)

2) C. Nishino, T. R. Tobin \& W. S. Bowers: $J$. Insect Physiol. 23, 415 (1977)

3) S. Takahashi, C. Kitamura \& I. Horibe: Agric. Biol. Chem. 42, 79 (1978)

4) C. J. Persoons, P. E. J. Verwiel, E. Talman \& F. J. Ritter: J. Chem. Ecol. 5, 221 (1979)

5) W. C. Still: J. Am. Chem. Soc. 101, 2493 (1979)

6) M. A. Adams, K. Nakanishi, W. C. Still, E. V. Arnold, J. Clardy \& C. J. Persoons: J. Am. Chem. Soc. 101, 2495 (1979)

7) E. Talman, P. E. J. Verwiel, F. J. Ritter \& C. J. Persoons: Isr. J. Chem. 17, 227 (1978)

8) C. J. Persoons, P. E. J. Verwiel, F. J. Ritter \& W. J. Nooyen: J. Chem. Ecol. 8, 439 (1982)

9) C. Nishino \& S. Manabe: Experientia, 39, 1340 (1983)

10) C. Nishino, T. R. Tobin \& W. S. Bowers: Appl. Entomol. Zool. 12, 287 (1977)

11) C. Nishino, H. Takayanagi \& S. Manabe: Agric. Biol. Chem. 46, 2781 (1982)

12) C. Nishino, S. Manabe, K. Kuwabara, R. Kimura \& H. Takayanagi: Insect. Biochem. 13, 65 (1983)

13) M. Niwa, M. Iguchi \& S. Yamamura: Chem. Pharm. Bull. 28, 997 (1980)

14) C. Nishino, H. Takayanagi \& R. Kimura: Comp. Biochem. Physiol. 66A, 393 (1980)

15) M. Burrows, J. Boeckh \& J. Esslen: J. Comp. Physiol. A, 145, 447 (1982)

16) T. L. Payne \& J. N. Dickens: J. Insect Physiol. 22, 1569 (1976)

17) J. C. Dickens \& T. L. Payne: J. Insect Physiol. 23, 481 (1977)

18) T. C. Baker \& W. L. Roelofs: J. Insect Physiol. 22, 1357 (1976)

19) S. Manabe \& C. Nishino: J. Chem. Ecol. 9, 433 (1983)

20) M. Niwa, M. Iguchi \& S. Yamamura: Tetrahedron Lett. 1979, 4291

21) C. Nishino \& H. Washio: Appl. Entomol. Zool. 11, 222 (1976)

22) H. Washio \& C. Nishino: J. Insect Physiol. 22, 735 (1976)

23) H. Sass: J. Comp. Physiol. 107, 49 (1976) 
要 約

ワモンゴキブリの性フェロモンミミクである germacrene-D の応差飽和触角電図

西野親生, 真部俊一 ワモンゴキブリの性フェロモンミミクである germacrene-D (1) と, 天然の性フェロモンである periplanoneB (3) との構造が類似しているが，この 2 物質間の構造 的相関は明確には説明されていない. 本研究では, 1 に 対する受容器を知るために，1 のほかに性フェロモンで
ある periplanone-A (2) と 3 および camphor を刺激物 質とした応差飽和触角電図法 (DS-EAG) を応用した。 1 で飽和したときに生じる 2 および 3 による二次的な $\mathrm{EAG}$ 反応, 同様に 2 で飽和した場合の 1 と 3 の反応, そして 3 で飽和したときの 1,2 による二次反忘から， 1 は 2 および 3 の受容器に受容されるが, 2 の受容器 に受容される可能性のほうがより大きいことがわかっ た.この結果は， 1 と 2 の構造的な関連性を新たに示唆 するものであった. 